Bngladesh J. Bot. 42(2): 327-332, 2013 (December)

\title{
CHEMICAL COMPOSITION AND ANTIOXIDANT ACTIVITY OF ESSENTIAL OILS OF THREE ENDEMIC MEDICINAL PLANTS OF IRAN
}

\author{
Abdollah Ghasemi Pirbalouti ${ }^{1 *}$, Leila Sedaghat ${ }^{2}$, Behzad Hamedi \\ AND FARHANG TIRgIR ${ }^{3}$ \\ Department of Medicinal Plants, Research Center for Medicinal Plants \& Ethnoveterinary, \\ Shahrekord Branch, Islamic Azad University, PO. Box: 166, Shahrekord, Iran
}

Key words: Chemical composition, Antioxident activity, Essential oil, Endemic plants. Iran

\begin{abstract}
Hydro-distillated essential oils (EO) antioxidant activity of three endemic medicinal plants of Iran namely, Heracleum lasiopetalum Boiss., Kelussia odoratissima Mozaff., and Ferulago angulata (Schlecht.) Boiss were studied. The results indicated that the major components of the EOs were 2-ethylhexyl acetate (34.5\%), $n$-octanol (6.5\%), and hexanol (5.1\%) for H. lasiopetalum fruits; Z- $\beta$-ocimene (20.5), $\alpha$-pinene (11.6\%), and $\alpha$-phellandrene (9.3) for $F$. angulata aerial parts; $\alpha$-pinene (20.1\%), 1,8 -cineole (18.2\%), and $Z$ ligustilide $(15.5 \%)$ for $K$. odoratissima aerial parts. The three EOs having high antioxidant activity could be used as an alternative preservative instead of synthetic ones in food industry.
\end{abstract}

\section{Introduction}

The essential oil (EO) and extracts from medicinal and aromatics plans may contain a wide variety of free radical scavenging molecules, such as phenolic compounds, nitrogen compounds, vitamins, terpenoids, and some other endogenous metabolites, which are rich in antioxidant activity (Shahidi and Naczk 1995, Velioglu et al. 1998, Cai et al. 2004). Studies demonstrate the medicinal activities, in particular antioxidant activities, of natural plant materials against various diseases such as atherosclerosis, cancer, diabetes, Alzheimer's, HIV, Parkinson's, and cataracts (Moon and Shibamoto 2009). In addition, interest has increased considerably in finding naturally occurring antioxidants for use in foods or medicinal materials to replace synthetic antioxidants, which are being restricted due to their carcinogenicity (Velioglu et al. 1998).

The family Apiaceae has more than 300 genera and 3000 species of the aromatics. Plants of this family can produce monoterpenes, sesquiterpenes, and phenyl components and related resins in their secretary ducts, roots, stem, leaf, flowers, seeds, and fruits (Sodeifian and Ansari 2011). In the present study, the antioxidant activity of EOs from three species of Iranian medicinal herbs (Apiaceae), namely Heracleum lasiopetalum Boiss., Kelussia odoratissima Mozaff., and Ferulago angulata (Schlecht) Boiss. were measured for natural antioxidants.

All these three species are endemic to Iran and their description, distribution and ethnobotanical properties having been described elsewhere (Ghasemi Pirbalouti 2009, 2010, Javidnia et al. 2006, Mozaffarian 2008; Rabbani et al. 2011).

So far, a few reports on chemical composition and antioxidant activity of the EOs of $H$. lasiopetalum fruits, F. angulata aerial parts and K. odoratissima aerial parts from Bakhtiari Zagros Mountains are available. The objective of the present study was to evaluate the antioxidant activity, and chemical composition of the EOs from three medicinal and aromatic plants of Iran.

*Author for correspondence: <ghasemi@iaushk.ac.ir>. ${ }^{1}$ Department of Medicinal Plants, Shahrekord Branch, Islamic Azad University, PO Box: 166, Shahrekord. ${ }^{2}$ Department of Food Sciences, Shahrekord Branch, Islamic Azad University, PO Box: 166, Shahrekord, Iran. ${ }^{3}$ Department of Chemistry, Shahrekord Branch, Islamic Azad University, PO Box: 166, Shahrekord, Iran. 


\section{Materials and Methods}

The fruits of $H$. lasiopetalum and the aerial parts (leaves and stem) of $F$. angulata and $K$. odoratissima were collected from mountains of Zagros, southwestern Iran, during May-June, 2012. Collected specimens were properly processed. Identifications were consequently confirmed with the help of the authentic specimens deposited at the Herbarium of Research Center of Agriculture and Natural Resources of Chaharmahal va Bakhtiari (CHB) and I.A.U. Shahrekord Branch (IAUSHK), Iran. Voucher number of $F$. angulata, $K$. odoratissima and $H$. lasiopetalum are CHB-1712, IAUSHK-150, IAUSHK-149, respectively.

Harvested parts were dried at room temperature for two weeks. Dried plant materials were powdered $(100 \mathrm{~g})$ and subjected to hydro-distillation (1000 $\mathrm{ml}$ distillated water) for $3 \mathrm{hrs}$ using a Clevenger-type apparatus.

The antioxidant capacity of the essential oils was evaluated by the method of Wang et al. (1998). The EOs at concentrations of $8-500 \mu \mathrm{g} / \mathrm{ml}$ were mixed with an equal volume of $0.2 \mathrm{mM}$ ethanol solution of DPPH. The absorbance was measured using a Perkin-Elmer Lambda UV/Vis spectrophotometer at $515 \mathrm{~nm}$ against a blank, i.e. without DPPH. All tests were run in triplicate and an average was used. Decreasing of DPPH solution absorbance indicates an increase of DPPH radical scavenging activity. The amount of sample necessary to decrease the absorbance of DPPH by $50 \%$ (IC50) was calculated graphically and the percentage inhibition was calculated according to the equation:

$$
\% \text { inhibition }=\frac{\mathrm{AC}(0)-\mathrm{AA}(\mathrm{t})}{\mathrm{AC}(0)} \times 100
$$

where $A_{C(0)}$ is the absorbance of the control at $t=0$ min and $A_{A(t)}$ is the absorbance of the antioxidant at $\mathrm{t}=30 \mathrm{~min}$. The food preservative butylhydroxyanisole (BHA) was used as positive control.

Gas chromatography/mass spectrometry (GC/MS) analysis: The EOs were analyzed using an Agilent 7890 A gas chromatograph (Agilent Technologies, Palo Alto, CA, USA) with a HP-5MS $5 \%$ phenylmethylsiloxane capillary column $(30.00 \mathrm{~m} \times 0.25 \mathrm{~mm}, 0.25 \mu \mathrm{m}$ film thickness $)$. Oven temperature was kept at $60^{\circ} \mathrm{C}$ for $4 \mathrm{~min}$ initially, and then raised at the rate of $4^{\circ} \mathrm{C} / \mathrm{min}$ to $260^{\circ} \mathrm{C}$. Injector and detector temperatures were set at 290 and $300^{\circ} \mathrm{C}$, respectively. Helium was used as carrier gas at a flow rate of $2 \mathrm{ml} / \mathrm{min}$, and $0.1 \mu \mathrm{l}$ samples were injected manually in the split mode. Peaks area per cents were used for obtaining quantitative data. The gas chromatograph was coupled to an Agilent $5975 \mathrm{C}$ (Agilent Technologies, Palo Alto, CA, USA) mass selective detector. The EI-MS operating parameters were as follows: Ionization voltage, $70 \mathrm{eV}$; Ion source temperature, $200^{\circ} \mathrm{C}$. Retention indices were calculated for all components using a homologous series of $n$-alkanes $\left(\mathrm{C}_{5}-\mathrm{C}_{24}\right)$ injected in conditions equal to samples ones. Identification of oil components was accomplished based on comparison of their retention times with those of authentic standards and by comparison of their mass spectral fragmentation patterns (WILLEY/ChemStation data system) (Adams 2007).

The data was statistically analyzed using one-way ANOVA by the program SPSS ${ }_{(19.0)}$, and comparison of the means of the main constituents of essential oils evaluated by Duncan's multiple range test at $\mathrm{p} \leq 0.05$ level.

\section{Results and Discussion}

The yellow oil of $F$. angulata and $K$. oderatissma, and opaque-yellow color oil of $H$. lasipetalum were obtained in the yields of $0.81,0.53$, and $0.35 \%(\mathrm{v} / \mathrm{w})$ based on dry matter, respectively. The EO yield and its chemical composition were expected as they are affected by 
several factors, including species and genotype (Ghasemi Pirbalouti et al. 2013a,b), ecological conditions (Ghasemi Pirbalouti and Moalem 2013), growth stage, and extraction methods (Sodeifian and Ansari 2011). Sodeifian and Ansari (2011) reported the oil yield of $F$. angulata under various factors in supercritical extraction method is highly variable ( 0.05 to $0.82 \%)$. Results of other study (Aklaghi 2008) indicated the flower, stem, and leaves of $F$. angulata (collected from east-north, Iran) yielded $0.66,0.54$ and $0.43 \%(\mathrm{w} / \mathrm{w})$, respectively. In agreement with previously published reports, Rabbani et al. (2011) reported that the aerial parts of $K$. odoratissima yielded a $0.4 \%(\mathrm{v} / \mathrm{w})$. The results of a study (Sonboli et al. 2006) indicated the EO yield of the aerial parts (leaves and stem) of T. lasiopetalum (synonym: H. lasiopetalum) collected from west Iran was $0.03 \%(\mathrm{w} / \mathrm{w})$ based on the dry weight of plant.

The chemical constituents identified by GC and GC/MS, the major components of the essential oils are presented in the Table 1. In total, 42 compounds in the EO from $F$. angulata were identified. The major components were $Z$ - $\beta$-Ocimene $(20.54 \%), \alpha$-pinene $(11.59 \%)$ and $\alpha$ phellandrene $(9.33 \%)$ that they were dominant among monoterpenes components (Table 1). The following components (\%) have been identified in EO of $F$. angulata two ecotypes: $E$ - $\beta$-ocimene (22.6-27.9), $\alpha$-pinene (25.7-27.1\%), bornyl acetate (3.9-8.5\%) (Ghasempour et al. 2007). The aerial parts of $F$. angulata in which (Z)- $\beta$-ocimene $(35.5 \%)$, terpinolene $(5.7 \%)$, and $\alpha$ phellandrene (5.4\%) have been the main components (Javidnia et al. 2006). Aklaghi (2008) reported that $\alpha$-phellandrene and $\alpha$-pinene are main compositions in flowers, stems, and leaves of F. angulata.

Table 1. Chemical compositions of the essential oils of three Iranian medicinal and aromatic plants.

\begin{tabular}{lccccc}
\hline Components & RI & KI & \multicolumn{3}{c}{ Percentage } \\
\cline { 4 - 6 } & & & $F$. angulata & H. lasipetalum & K. oderatissma \\
\hline$\alpha$-Thujan & 930 & 931 & 0.67 & 0.11 & 0.16 \\
$\alpha$-Pinene & 939 & 939 & $\mathbf{1 1 . 5 9}$ & 4.82 & $\mathbf{2 0 . 0 9}$ \\
Camphene & 951 & 953 & 1.06 & - & 0.13 \\
Verbenene & 967 & 967 & 0.69 & - & - \\
Sabinene & 981 & 976 & 1.37 & 0.56 & - \\
$\beta$-Pinene & 985 & 980 & 1.33 & 0.48 & 0.44 \\
$\beta$-Myrcene & 995 & 991 & 3.42 & 0.22 & 0.31 \\
$\alpha$-Pphellandrene & 1008 & 1005 & $\mathbf{9 . 3 3}$ & 0.57 & 0.36 \\
$\Delta$-3-Carene & 1012 & 1011 & 1.24 & 0.09 & 0.26 \\
$\alpha$-Terpinene & 1017 & 1018 & 0.29 & - & 0.10 \\
$p$-Cymene & 1025 & 1026 & 2.02 & 0.22 & 0.70 \\
$\beta$-Phellandrene & 1030 & 1031 & $\mathbf{8 . 1 1}$ & 0.89 & - \\
1,8 -Cineole & 1030 & 1033 & - & 2.18 & $\mathbf{1 8 . 1 7}$ \\
$Z$ - $\beta$-Ocimene & 1041 & 1040 & $\mathbf{2 0 . 5 4}$ & 2.10 & 1.03 \\
$E$ - $\beta$-Ocimene & 1048 & 1050 & 3.23 & 0.25 & 0.32 \\
-Terpinene & 1058 & 1062 & 0.65 & 0.08 & 0.36 \\
$n$-Octanol & 1072 & 1070 & - & $\mathbf{6 . 5 0}$ & - \\
$E$-Linalool oxide & 1072 & 1074 & 0.05 & - & 0.15 \\
Terpinolene & 1088 & 1088 & 2.24 & 0.26 & 0.59 \\
Camphenone & 1096 & 1093 & 0.29 & - & - \\
\hline & & & & & $($ Contd.)
\end{tabular}




\begin{tabular}{|c|c|c|c|c|c|}
\hline Linalool & 1104 & 1098 & 2.98 & 1.33 & 10.66 \\
\hline Alloocimene & 1126 & 1123 & 1.25 & 0.09 & - \\
\hline Z-Pinocarveol & 1134 & 1139 & - & - & 0.37 \\
\hline$E$-Verbenol & 1138 & 1140 & 0.95 & - & - \\
\hline$Z$-Verbenol & 1143 & 1144 & 2.79 & - & - \\
\hline Citronella & 1150 & 1153 & 0.18 & - & - \\
\hline Borneol & 1065 & 1165 & - & - & 0.12 \\
\hline Terpinene-4-ol & 1175 & 1166 & 0.78 & - & 0.38 \\
\hline$\alpha$-Terpineol & 1187 & 1189 & 0.67 & 1.03 & 5.28 \\
\hline Hexanol & 1197 & 1203 & - & 5.12 & - \\
\hline Z-Carveol & 1215 & 1217 & - & - & 0.21 \\
\hline Octanol acetate & 1216 & 1211 & - & 34.48 & - \\
\hline Citronellol & 1224 & 1228 & 1.32 & - & - \\
\hline Nerol & 1225 & 1228 & - & - & 0.24 \\
\hline Pulegone & 1235 & 1237 & - & - & 0.39 \\
\hline Geraniol & 1250 & 1255 & 0.31 & 0.45 & - \\
\hline E-Anethole & 1280 & 1282 & - & - & 0.22 \\
\hline Bornyl acetate & 1280 & 1285 & 2.39 & - & - \\
\hline Thymol & 1286 & 1290 & 0.15 & 0.34 & 0.99 \\
\hline Carvacrol & 1295 & 1298 & 1.98 & 0.60 & 1.51 \\
\hline$\alpha$-Terpinyl acetate & 1344 & 1350 & - & 0.31 & - \\
\hline Citronellyl acetate & 1348 & 1354 & $\operatorname{tr}$ & - & - \\
\hline Neryl acetate & 1369 & 1365 & - & 0.22 & - \\
\hline$\alpha$-Copaene & 1369 & 1376 & 0.14 & 0.21 & 0.55 \\
\hline$\beta$-Elemene & 1386 & 1391 & 0.05 & - & - \\
\hline E-Jasmone & 1393 & 1394 & 0.45 & - & - \\
\hline Methyleugenol & 1399 & 1402 & 0.41 & - & - \\
\hline$\beta$-Caryophyllene & 1412 & 1418 & 0.81 & 0.38 & 0.52 \\
\hline$\alpha$-Humulene & 1446 & 1440 & 0.09 & 0.29 & 0.46 \\
\hline Z- $\beta$-Farnesene & 1452 & 1443 & - & 0.08 & - \\
\hline -Curcumene & 1473 & 1480 & 0.40 & - & - \\
\hline Germacrene D & 1474 & 1480 & - & 0.52 & 0.32 \\
\hline$\alpha$-Curcumene & 1477 & 1483 & - & 0.39 & - \\
\hline$\alpha$-Zingibirene & 1489 & 1495 & - & 0.70 & - \\
\hline Bicyclogermacrene & 1490 & 1494 & 4.03 & - & - \\
\hline$\beta$-Himachalene & 1492 & 1499 & - & - & 0.41 \\
\hline Cuparene & 1498 & 1502 & - & 0.11 & 0.22 \\
\hline$\beta$-Bisabolene & 1502 & 1509 & 0.12 & 0.47 & 0.10 \\
\hline$E$ - -Bisabolene & 1508 & 1515 & - & 0.21 & 0.18 \\
\hline$\delta$-Cadinene & 1516 & 1524 & 0.46 & - & 0.40 \\
\hline$\beta$-Sesquiphellandrene & 1516 & 1524 & - & 0.53 & - \\
\hline$Z$ - -Bisabolene & 1524 & 1533 & - & 0.11 & - \\
\hline Spathulenol & 1569 & 1576 & 0.45 & - & - \\
\hline Caryophyllene oxide & 1573 & 1581 & - & 0.17 & 0.37 \\
\hline Z-3-Butylidene phthalide & 1662 & 1668 & - & 1.01 & 0.87 \\
\hline$Z$-Ligustilide & 1727 & 1726 & - & - & 15.52 \\
\hline Total & & & 91.32 & 68.48 & 83.46 \\
\hline Oil yield v/w (\%) & & & 0.81 & 0.35 & 0.53 \\
\hline
\end{tabular}

tr: $(<0.05 \%)$. RI: Retention indices determined on HP-5MS capillary column. KI: Kovats index. \%: Calculated from TIC data. 
In total, 38 compounds in the EO from $K$. odoratissima were identified; the major compounds were $\alpha$-pinene (20.1\%), 1,8-cineole (18.2\%), and $Z$-ligustilide $(15.5 \%)$, while the results of other reports indicated that the main components of the EO of $K$. odoratissima were 3- $n$ butyl phtalide and Z-ligustilide (Rabbani et al. 2011; Ghasemi Pirbalouti et al. 2012; Sajjadi et al. 2013). Various factors, including ecotype, harvesting stage, drying, and extraction methods caused on this variation.

Results of current study indicated that 39 compounds were identified in the EO of $H$. lasiopetalum. As a determined by $\mathrm{GC}$ and $\mathrm{GC}-\mathrm{MS}$ analyses, $H$. lasiopetalum contained 2ethylhexyl acetate (34.5\%), $n$-octanol $(6.5 \%)$ and hexanol $(5.1 \%)$ as the major compounds. Sesquiterpene hydrocarbons were found as the major group of compounds in H. lasiopetalum. (E)anethole has been characterized as the main constituent of the leaves, stem and flower of $H$. persicum Desf. ex Fisch from Iran (Sefidkon et al. 2002, 2004).

Antioxidant properties are very important in counteracting the deleterious role of free radicals in foods or biological systems. Excessive formation of free radicals accelerates the oxidation of lipids in foods, impairs food quality and consumer acceptance (Cheung et al. 2007). The DPPH is a stable free radical, which has been widely accepted as a tool for estimating the free radical scavenging activities of antioxidants ( $\mathrm{Hu}$ et al. 2004). The lower $\mathrm{IC}_{50}$ value indicates a stronger ability of the extract to act as a DPPH scavenger while the higher $\mathrm{IC}_{50}$ value indicates a lower scavenging activity of the scavengers as more scavengers were required to achieve $50 \%$ scavenging reaction. The $\mathrm{IC}_{50}$ values were found to be $0.035,0.027,0.028$, and $0.065 \mathrm{mg} / \mathrm{ml}$ for $K$. odoratissima, $H$. lasiopetalum, $F$. angulata, and L-Ascorbic acid, respectively. The results indicated no significant difference between activities of the EOs. An important characteristic of EO and their components is their hydrophobicity, which enables them to partition in the lipids of the bacterial cell membrane and mitochondria, disturbing the structures and rendering them more permeable. Leakage of ions and other cell contents can then occur. Free radicals cause auto oxidation of unsaturated lipids in food, and the antioxidant activity of the EOs could be attributed to their hydrogen donating ability (Kaur and Perkins 1991).

The results of this study suggest the possibility of using the EOs as natural food preservatives, because the EOs possesses high antioxidant activities. This study can be considered as the first report on the in vitro antioxidant activity of the EOs prepared from the aerial parts of $K$. odoratissima and F. angulata and fruits of H. lasiopetalum, collected from Southwestern Iran. We hope that our results introduce a unique natural source which possesses strong antioxidant substances.

\section{Acknowledgment}

Helps extended by Mr. Shirmardi for this research is thankfully acknowledged.

\section{References}

Adams RP 2007. Identification of Essential Oil Components by Gas ChromatographyMass Spectrometry, 4th edition. Allured Publishing Corporation, Carol Stream, Illinois.

Akhlaghi H 2008. The essential oils from flowers, stems and leaves of Ferulago angulata from Iran. Chemistry Natural Compounds 44: 396-397.

Cai YZ, Luo Q, Sun M, Corke H 2004. Antioxidant activity and phenolic compounds of 112 traditional Chinese medicinal plants associated with anticancer. Life Science 74(17): 2157-2184.

Cheung SCM, Szeto YT, Benzie IFF 2007. Antioxidant protection of edible oils. Plant Foods for Human Nutrition 62: 39-42.

Ghasemi Pirbalouti A 2009. Medicinal plants used in Chaharmahal and Bakhtyari districts, Iran. Herba Polonica 55: 69-75. 
Ghasemi Pirbalouti A 2010. Medicinal and aromatic plants. $3^{\text {th }}$ Ed. I.A.U. Shahrekord Branch Press. pp. 550. Shahrekord. Iran.

Ghasemi Pirbalouti A and Moalem E 2013. Variation in antibacterial activity of different ecotypes of Satureja khuzestanica Jamzad, as an Iranian endemic plant. Indian Journal of Traditional Knowledge, 12(4), 623-629.

Ghasemi Pirbalouti A, Aghaee K, Kashi AK, Malekpoor F 2012. Chemical composition of the essential oil of wild and cultivated plant populations of Kelussia odoratissima Mozaff. Journal of Medicinal Plants Reseaerch 6: 449-454.

Ghasemi Pirbalouti A, Hashemi M, Taherian Ghahfarokhi F 2013a. Essential oil and chemical compositions of wild and cultivated Thymus daenensis Celak and Thymus vulgaris L. Industrial Crops and Products 48: $43-48$.

Ghasemi Pirbalouti A, Fatahi M, Craker L, Shirmardi H 2013b. Chemical composition and bioactivity of essential oils of Hypericum helianthemoides, Hypericum perforatum and Hypericum scabrum. Pharmaceutical Biology 2013: 1-7.

Ghasempour H, Shirinpour E, Heidari H 2007. Analysis by Gas Chromatography-mass spectrometry of essential oil from seeds and aerial parts of Ferulago angulata (Schlecht.) Boiss gathered in Nevakoh and Shahoo, Zagross Mountain, West of Iran. Pakistan Journal of Biological Science 10(5): 814-817.

Javidnia K, Miri R, Edraki N, Khoshneviszadeh M, Javidnia A 2006. Constituents of the volatile oil of Ferulago angulata (Schlecht.) Boiss. from Iran. Journal of Essential Oil Research 18: 548-50.

Kaur H, Perkins J 1991. The free radical chemistry of food additives. In: free radicals and food additives, Aruoma, O.I. and B. Halliwell (Eds.). Taylor and Francis Ltd., London, UK. pp: 17-35.

Khanahmadi M, Janfeshan K 2006. Study on anti-oxidation property of Ferulago angulata plant. Asian Journal of Plant Science 5: 521-526.

Lee YM, Kim H, Hong EK, Kang BH, Kim SJ 2000. Water extract of 1:1 mixture of Phellodendron cortex and Aralia cortex has inhibitory effects on oxidative stress in kidney of diabetic rats. Journal of Ethnopharmacology 73: 429-436.

Moon JK and Shibamoto T 2009. Antioxidant assays for plant and food components. J. Agric Food Chem. 57: 1655-1666.

Mozaffarian V 2008. A pictorial dictionary of botany botanical taxonomy. Latin - English - French Germany - Persian/ Complied, Farahang Moaser, Tehran, p. 522, 2008.

Rabbani M, Sajjadi SE, Sadeghi M 2011. Chemical composition of the essential oil from Kelussia odoratissima mozaff. and the evaluation of its sedative and anxiolytic effects in mice. Clinics 66(5): 843-848.

Sajjadi SE, Y Shokoohinia, P Mehramiri 2013. Isolation and characterization of steroids, phthalide and essential oil of the fruits of Kelussia odoratissima Mozaff., an endemic mountain celery. Research in Pharmaceutical Sciences 8(1): 35-41.

Sefidkon F, Dabiri M, Mohammad N 2002. Analysis of the oil of Heracleum persicum L. (leaves and flowers). Journal of Essential Oil Research 14: 295-297.

Sefidkon F, Dabiri M, Mohammad N 2004. Analysis of the oil of Heracleum persicum L. (Seeds and Stems). Journal of Essential Oil Research 16: 296-298.

Shahidi F and Naczk M 1995. Food Phenolics: Sources, Chemistry, Effects and Applications. Technomic Pub. Co., Basel, Switzerland.

Sodeifian G and Ansari K 2001. Optimization of Ferulago angulata oil extraction with supercritical carbon dioxide. Journal of Supercritical Fluid 57: 38.

Sonboli A, Azizian D, Yousefzadi M, Kanani MR, Mehrabian AR 2007. Volatile constituents and antimicrobial activity of the essential oil of Tetrataenium lasiopetalum (Apiaceae) from Iran. Flavour Fragrans Journal 22(2): 119-122.

Velioglu YS, Mazza G, Gao L, Oomah BD 1998. Antioxidant activity and total phenolics in selected fruits, vegetables, and grain products. Journal of Agricultural and Food Chemistry 46(10): 4113-4117.

Wang M, Li J, Rangarajan M, Shao Y, La Voie EJ, Huang CT and Ho CT 1998. Antioxidative phenolic compounds from sage (Salvia officinalis). J. Agric. Food Chem. 46: 4869-4873. 